\begin{tabular}{|c|c|}
\hline Title & $\begin{array}{l}\text { Selective introduction of a fluorine atom into carbohydrates and a nucleoside by ring-opening fluorination reaction of } \\
\text { epoxides }\end{array}$ \\
\hline Author(s) & A kiyama, Y uriko; Hiramatsu, Chiharu; Fukuhara, Tsuy oshi; Hara, Shoji \\
\hline Citation & $\begin{array}{l}\text { Journal of Fluorine Chemistry, } 127(7), 920-923 \\
\text { https://doi.org/10.1016/.jfluchem.2006.04.001 }\end{array}$ \\
\hline Issue Date & $2006-07$ \\
\hline Doc URL & http:/hdl.handle.net/2115/14466 \\
\hline Type & article (author version) \\
\hline File Information & jfluchem_127(7)_920-923.pdf \\
\hline
\end{tabular}

Instructions for use 


\title{
Selective introduction of a fluorine atom into carbohydrates and a nucleoside by ring-opening fluorination reaction of epoxides
}

Yuriko Akiyama, Chiharu Hiramatsu, Tsuyoshi Fukuhara, Shoji Hara*

Graduate School of Engineering, Hokkaido University, Sapporo 060-8628, Japan

\begin{abstract}
Ring-opening fluorination reactions of epoxides using tetrabutylammonium bifluoride (TBABF) $-\mathrm{KHF}_{2}$, or $\mathrm{Et}_{3} \mathrm{~N}-3 \mathrm{HF}$ under microwave irradiation were applied for the introduction of a fluorine atom into the carbohydrate molecules. When TBABF-KHF 2 was used as the fluorination reagent, a fluorine atom was introduced regioselectively and various functional groups can tolerate the conditions. When $\mathrm{Et}_{3} \mathrm{~N}-3 \mathrm{HF}$ was used under microwave irradiation, the reaction time could be remarkably shortened compared with the conventional oil-bath heating.
\end{abstract}

Keywords: Fluorinated carbohydrates; Ring-opening fluorination; Epoxides; Microwave

\section{Introduction}

Fluorinated carbohydrates have recently received much attention because of their important role in the study of enzyme-carbohydrate interactions as well as their interesting biological activities [1,2] and application for positron emission tomography [3]. The ring-opening fluorination reactions of epoxides have been used to introduce a fluorine atom into the carbohydrate molecules [4-6]. However, problems such as regioselectivity, formation of undesired by-products, and long reaction time remained unsolved [7,8]. Recently, we found that tetrabutylammonium bifluoride (TBABF)-KHF 2 shows good regioselectivity in ring-opening fluorination of terminal epoxides [9]. We also found that application of microwave

*Corresponding author. Fax: +81-11-706-6556

email address. shara@eng.hokudai.ac.jp 
irradiation to the ring-opening fluorination of epoxides using $\mathrm{Et}_{3} \mathrm{~N}-3 \mathrm{HF}$ can remarkably shorten the reaction time [10]. We applied these methods to the fluorinated carbohydrate and nucleoside synthesis, and succeeded in improving the yield, selectivity, and/or shortening the reaction time.

\section{Results and Discussion}

2.1. Fluorinated carbohydrates synthesis using $\mathrm{TBABF}^{-\mathrm{KHF}_{2}}$ or $\mathrm{Et}_{3} \mathrm{~N}-3 \mathrm{HF}$ under microwave irradiation

2,3,6-Trideoxy-6-fluoro- $D$-arabino-hexano-1,4-lactone (2) was previously prepared from an epoxide (1) by the ring-opening fluorination using tetrabutylammonium dihydrogen trifluoride (TBATF)- $\mathrm{KHF}_{2}$ [7] or $\mathrm{Et}_{3} \mathrm{~N}-3 \mathrm{HF}$ [8] in $70 \%$ or $55 \%$ yield, respectively. However, long time was required to complete the reactions (at $75^{\circ} \mathrm{C}$ for $39 \mathrm{~h}$ or at $70{ }^{\circ} \mathrm{C}$ for 3 days, respectively). When TBABF-KHF 2 was used for the reaction with 1, it failed to improve the result (Entry 1 in Table 1). On the other hand, under the microwave irradiation condition, the reaction of $\mathbf{1}$ with $\mathrm{Et}_{3} \mathrm{~N}-3 \mathrm{HF}$ was completed in 10 min and 2 was obtained in 80\% yield (Entry 2). Not only could the reaction time be remarkably shortened but also the yield could be improved. Application of the microwave irradiation method was found to be effective to shorten the reaction time in the fluorination of 2-deoxy-5,6-epoxy- $D$-arabino-hexano-1,4-lactone (3) with $\mathrm{Et}_{3} \mathrm{~N}-3 \mathrm{HF}$, and the fluorinated product was isolated as a diacetate (4) in 67\% yield after the microwave irradiation for $25 \mathrm{~min}$ at $120{ }^{\circ} \mathrm{C}$ (Entry 3). The reaction of 3 with $\mathrm{Et}_{3} \mathrm{~N}-3 \mathrm{HF}$ was 
previously carried out under conventional oil-bath heating and it took 3 days at $70{ }^{\circ} \mathrm{C}$ to obtain the fluorinated product in 65\% yield [8]. A 6-fluoro-6-deoxy- $D$-glucofuranose derivative (6), which was previously prepared by nucleophilic substitution reaction from cyclic sulfonate of the diol [11,12], was directly prepared from an epoxide (5). The fluorination of 5 with $\mathrm{TBABF}-\mathrm{KHF}_{2}$ regioselectively proceeded at $70{ }^{\circ} \mathrm{C}$ in $48 \mathrm{~h}$ to give 6 in $78 \%$ yield (Entry 4), while the reaction of 5 with $\mathrm{Et}_{3} \mathrm{~N}-3 \mathrm{HF}$ was completed in 45 min at $120{ }^{\circ} \mathrm{C}$ under microwave irradiation to give 6 in $74 \%$ yield without formation of the regioisomer (Entry 5). In these reactions, the products could be obtained with higher regioselectivity than in the cases of simple terminal epoxides $[9,10]$. The high selectivity can be attributed to an oxygen atom located at the $\alpha$-carbon of the epoxides [13]. The fluorination of an internal epoxide in methyl 2,3-anhydro- $\beta$ - $D$-ribopyranoside (7) was previously carried out using TBATF- $\mathrm{KHF}_{2}$ at $130{ }^{\circ} \mathrm{C}$ for $12 \mathrm{~h}$ and methyl 3-deoxy-3-fluoro- $\beta$ - $D$-xylopyranoside (8) was obtained in $70 \%$ yield with its regioisomer (6\%) [14]. When TBABF-KHF 2 was used, the reaction with 7 proceeded at $120^{\circ} \mathrm{C}$ in 5 h to selectively provide 8 in $70 \%$ yield (Entry 6). The reaction of 7 with $\mathrm{Et}_{3} \mathrm{~N}-3 \mathrm{HF}$ was completed in 30 min under the microwave irradiation and 8 was obtained in $55 \%$ yield (Entry 7). In both cases, formation of the regioisomer was not observed. 
Table 1

Fluorination of carbohydrates by ring-openin fluorination of epoxides

Entry

a. Isolation yield based on epoxide used. In parentheses, regioselectivity. Method A: If otherwise not mentioned, TBABF-KHF${ }_{2}$ was used without solvent. Method $\mathrm{B}$ : $\mathrm{Et}_{3} \mathrm{~N}-3 \mathrm{HF}$ was used without solvent under microwave irradiation. b. $\mathrm{CH}_{3} \mathrm{CN}$ was used as solvent. $\mathrm{C}$. Heptane was used as solvent.

2.2. Application for the fluorinated nucleoside derivative synthesis

Synthesis of nucleoside derivatives having fluorine atoms at the sugar part is of great interest because such analogs having important bioactivities such as antiviral and anticancer activities were found [15]. 2’-C- $\beta$-Fluoromethyluridine derivative (10) was recently prepared from the corresponding 2'- $\alpha$-spiroepoxyuridine derivative (9) by the reaction with $\mathrm{KHF}_{2}$ at $130{ }^{\circ} \mathrm{C}$ for $8 \mathrm{~h}$ [16]. However, the desired product 10 was 
obtained only in 35\% yield with many by-products including its regioisomer 11. When the reaction was carried out using TBABF-KHF 2 in $\mathrm{CH}_{3} \mathrm{CN}$, 11 could be obtained in 74\% yield without the formation of $\mathbf{1 1}$ (eq 1).

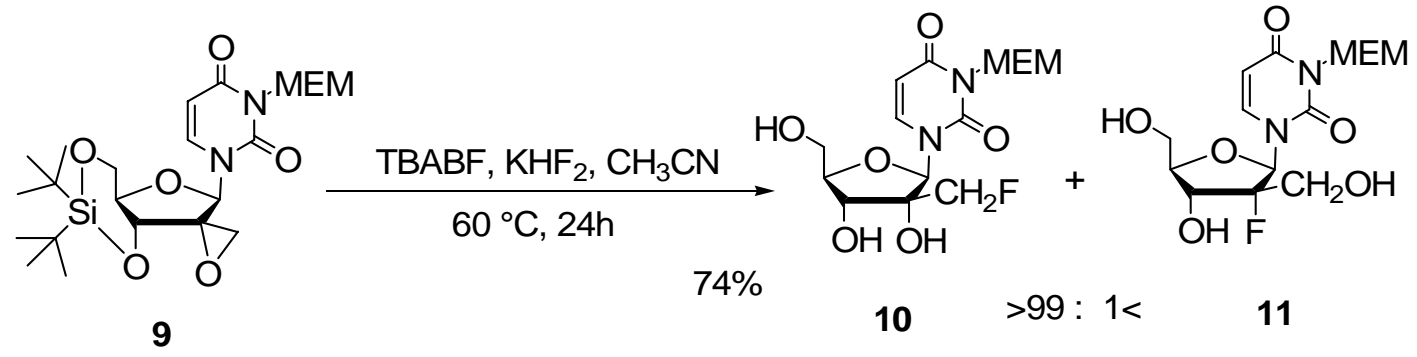

\section{Experimental}

\subsection{General Experimental Procedures}

The IR spectra were recorded using a JASCO FT/IR-410. The ${ }^{1} \mathrm{H}$ NMR (400 MHz), ${ }^{13} \mathrm{C}$ NMR (100 MHz), and ${ }^{19} \mathrm{~F}$ NMR (376 MHz) spectra were recorded in $\mathrm{CDCl}_{3}$ on a JEOL JNM-A400II FT NMR and the chemical shifts, $\delta$, are referred to TMS $\left({ }^{1} \mathrm{H}\right.$ and $\left.{ }^{13} \mathrm{C}\right)$ and $\mathrm{CFCl}_{3}\left({ }^{19} \mathrm{~F}\right)$, respectively. The EI-low and high-resolution mass spectra were measured on a JEOL JMS-700TZ, JMS-FABmate or JMS-HX110. Microwave irradiation was carried out using an IDX microwave oven for organic synthesis (0-300 W, IMCR-25003) equipped with a temperature control system. Compounds 1 [17], 3 [17], 5 [18], 7 [19], and 9 [16] were prepared according to literatures. $\mathrm{KHF}_{2}$ and $46 \%$ aq HF were purchased from Wako Pure Chemical Industries. Ltd. $\mathrm{Et}_{3} \mathrm{~N}-3 \mathrm{HF}$ and TBAF (1 M solution in THF) were purchased from Aldrich. 


\subsection{Preparation of $T B A B F$}

To a $1 \mathrm{M}$ THF solution of TBAF (30 ml, $30 \mathrm{mmol}$ ) in a glass flask was added $46 \%$ aq HF (1.3 g, $30 \mathrm{mmol}$ ), and the volatile part was removed by an evaporator. Complete removal of water gave pure $\mathrm{TBABF}$ as a highly viscous liquid which is difficult to handle. Therefore, we recommend removing the water completely just before use. ${ }^{1} \mathrm{H}$ NMR $\left(\mathrm{CD}_{2} \mathrm{Cl}_{2},-80{ }^{\circ} \mathrm{C}\right) \delta=16.23\left(\mathrm{t}, J_{\mathrm{HF}}=122.9 \mathrm{~Hz},{ }^{-} \mathrm{HF}_{2}\right)$ [lit. [20] $16.12\left(\mathrm{t}, J_{\mathrm{HF}}=\right.$ 122.7 Hz)], ${ }^{19} \mathrm{~F}$ NMR $\left(\mathrm{CD}_{2} \mathrm{Cl}_{2},-80{ }^{\circ} \mathrm{C}\right) \delta=-151.5\left(\mathrm{~d}, J_{\mathrm{HF}}=123.0 \mathrm{~Hz},{ }^{-} \mathrm{HF}_{2}\right)$ [lit. [20] $\delta=$ $\left.-147.5\left(\mathrm{~d}, J_{\mathrm{HF}}=123.3 \mathrm{~Hz}\right)\right]$

\subsection{Fluorinated carbohydrates synthesis}

\subsubsection{2,3,6-Trideoxy-6-fluoro-D-arabino-hexano-1,4-lactone (2) [7,8]}

Method A: A mixture of crude TBABF (423 mg, $1.5 \mathrm{mmol}$ ) and $\mathrm{KHF}_{2}$ (12 mg, 0.15 mmol) in a glass flask was kept at $100{ }^{\circ} \mathrm{C} / 0.55 \mathrm{mmHg}$ for 15 min to remove water completely. After cooling to room temperature, 1 (64 mg, $0.5 \mathrm{mmol}$ ) and $\mathrm{CH}_{3} \mathrm{CN}$ (1 ml) were added, and the mixture was stirred at $70{ }^{\circ} \mathrm{C}$ for $48 \mathrm{~h}$. After cooling to room temperature, water $(2 \mathrm{ml})$ and ether $(2 \mathrm{ml})$ were added. The separated aqueous layer was extracted with ether three times, and the combined organic phase was dried over $\mathrm{MgSO}_{4}$ and concentrated under reduced pressure. Purification by column chromatography (silica gel/AcOEt- $\mathrm{CH}_{2} \mathrm{Cl}_{2}$ ) gave 2 (47 mg, $0.32 \mathrm{mmol}$ ) in $63 \%$ yield.

Method B: To a reactor of a Teflon ${ }^{\mathrm{TM}}$ PFA tube with a diameter of $10 \mathrm{~mm}$ sealed at one end, 1 (64 mg, $0.5 \mathrm{mmol}$ ) and $\mathrm{Et}_{3} \mathrm{~N}-3 \mathrm{HF}(97 \mathrm{mg}, 0.6 \mathrm{mmol})$ were introduced. The 
open end of the reactor was connected to a reflux condenser. Then, the reactor part was submitted to microwave-irradiation for $10 \mathrm{~min}$ and during the irradiation, the temperature was kept at $140{ }^{\circ} \mathrm{C}$. After cooling, the reaction mixture was poured into an aq $\mathrm{NaHCO}_{3}$ solution. The product was extracted with ether three times and the combined ethereal layers were dried over $\mathrm{MgSO}_{4}$. Purification by column chromatography (silica gel/AcOEt- $\mathrm{CH}_{2} \mathrm{Cl}_{2}$ ) gave $2(59 \mathrm{mg}, 0.4 \mathrm{mmol})$ in $80 \%$ yield. Viscous liquid: IR (neat) 3429, 2963, 1774, $1192 \mathrm{~cm}^{-1} .{ }^{1} \mathrm{H}$ NMR $\delta=2.29-2.36(\mathrm{~m}$, 3H), 2.52-2.67 (m, 2H), 4.00-4.10 (dm, $J=19.4 \mathrm{~Hz}, 1 \mathrm{H}), 4.45-4.64(\mathrm{~m}, 3 \mathrm{H}) .{ }^{13} \mathrm{C}$ NMR $\delta=22.50,28.20,70.55\left(\mathrm{~d}, J_{\mathrm{C}-\mathrm{F}}=19.0 \mathrm{~Hz}\right), 79.17\left(\mathrm{~d}, J_{\mathrm{C}-\mathrm{F}}=5.8 \mathrm{~Hz}\right), 83.31\left(\mathrm{~d}, J_{\mathrm{C}-\mathrm{F}}\right.$ $=169.5 \mathrm{~Hz}), 177.56 .{ }^{19} \mathrm{~F}$ NMR $\delta=-235.27(\mathrm{dt}, J=19.4,47.0 \mathrm{~Hz}, 1 \mathrm{~F})$.

\subsubsection{2,6-Dideoxy-3,5-di-O-acetyl-6-fluoro-D-arabino-hexano-1,4-lactone (4)}

Method B: The fluorination reaction of 3 (72 $\mathrm{mg}, 0.5 \mathrm{mmol})$ was carried out using $\mathrm{Et}_{3} \mathrm{~N}-3 \mathrm{HF}$ (97 mg, $0.6 \mathrm{mmol}$ ) at $120^{\circ} \mathrm{C}$ for $25 \mathrm{~min}$ as in the case of $\mathbf{1}$. After the reaction, the mixture was poured into an aq $\mathrm{NaHCO}_{3}$ solution, extracted with ether three times, and dried over $\mathrm{MgSO}_{4}$. After concentration, $\mathrm{Ac}_{2} \mathrm{O}(1 \mathrm{ml})$ and $60 \%$ $\mathrm{HClO}_{4}(0.03 \mathrm{ml})$ were added and the mixture was stirred at room temperature overnight. The mixture was poured into an aq $\mathrm{NaHCO}_{3}$ solution, extracted with ether three times, and dried over $\mathrm{MgSO}_{4}$. After concentration, 4 (82 mg, $0.33 \mathrm{mmol}$ ) was isolated by column chromatography (silica gel/AcOEt- $\mathrm{CH}_{2} \mathrm{Cl}_{2}$ ) in $66 \%$ yield. White solid: mp $88{ }^{\circ} \mathrm{C} . \quad$ IR (KBr) 2969, 1783, 1740, 1254, $1041 \mathrm{~cm}^{-1} . \quad{ }^{1} \mathrm{H}$ NMR $\delta=2.06$ (s, 3H), 2.09 (s, 3H), 2.62 (d, $J=18.3 \mathrm{~Hz}, 1 \mathrm{H}), 2.92$ (dd, $J=18.3,5.5 \mathrm{~Hz}, 1 \mathrm{H}$ ), 4.60-4.79 (m, 3H), 5.27 (ddt, $J=27.4,9.8,2.4 \mathrm{~Hz}, 1 \mathrm{H}), 5.66$ (dd, $J=5.5,3.7 \mathrm{~Hz}, 1 \mathrm{H}) .{ }^{13} \mathrm{C}$ 
NMR $\delta=$ 20.68, 20.70, 36.62, 68.05 (d, $J=18.2 \mathrm{~Hz}), 68.47,77.13,81.65$ (d, $J=175.3$ Hz), 169.50 (2C), 172.68. ${ }^{19} \mathrm{~F}$ NMR $\delta=-236.80$ (dt, $J=24.0,47.0 \mathrm{~Hz}$ ). HRMS (EI): Calcd for $\mathrm{C}_{9} \mathrm{H}_{11} \mathrm{O}_{6}\left(\mathrm{M}^{+}-\mathrm{CH}_{2} \mathrm{~F}\right)$ : 215.0555, Found: 215.0543 .

\subsubsection{6-Deoxy-6-fluoro-1,2-O-isopropylidene- $\alpha$-D-glucofuranose (6) $[11,21]$}

Method A: The fluorination reaction of 5 (101 mg, $0.5 \mathrm{mmol})$ was carried out using TBABF (423 mg, $1.5 \mathrm{mmol}), \mathrm{KHF}_{2}(12 \mathrm{mg}, 0.15 \mathrm{mmol})$ and $\mathrm{CH}_{3} \mathrm{CN}(1 \mathrm{ml})$ at $70{ }^{\circ} \mathrm{C}$ for 48h as in the case of 1, and 6 (86 $\mathrm{mg}, 0.39 \mathrm{mmol}$ ) was isolated by column chromatography (silica gel/AcOEt-hexane) in 78\% yield.

Method B: The fluorination reaction of 5 (101 mg, $0.5 \mathrm{mmol})$ was carried out using $\mathrm{Et}_{3} \mathrm{~N}-3 \mathrm{HF}$ (805 $\mathrm{mg}, 5 \mathrm{mmol}$ ) at $120{ }^{\circ} \mathrm{C}$ for $45 \mathrm{~min}$ as in the case of 1, and 6 (82 $\mathrm{mg}$, $0.37 \mathrm{mmol}$ ) was isolated by column chromatography (silica gel/EtOAc-hexane) in 74\% yield. Viscous liquid: IR (neat) 3434, 2989, 1377, 1073, $1011 \mathrm{~cm}^{-1} .{ }^{1} \mathrm{H}$ NMR $\delta=$ 1.32 (s, 3H), 1.49 (s, 3H), 3.76 (brs, 2H), 4.09-4.21 (m, 2H), 4.37 (s, 1H), 4.54 (d, J =

3.4 Hz, 1H), 4.60-4.75 (m, 2H), 5.95 (d, $J=3.4 \mathrm{~Hz}, 1 \mathrm{H}) . \quad{ }^{13} \mathrm{C}$ NMR $\delta=26.04,26.63$, $68.87\left(\mathrm{~d}, J_{\mathrm{C}-\mathrm{F}}=19.0 \mathrm{~Hz}\right), 75.13,78.46\left(\mathrm{~d}, J_{\mathrm{C}-\mathrm{F}}=5.8 \mathrm{~Hz}\right), 84.68\left(\mathrm{~d}, J_{\mathrm{C}-\mathrm{F}}=169.5 \mathrm{~Hz}\right)$, 84.93, 104.82, 111.92. ${ }^{19}$ F NMR $\delta=-233.94(\mathrm{dt}, J=23.2,47.6 \mathrm{~Hz}, 1 \mathrm{~F})$.

\subsubsection{Methyl 3-deoxy-3-fluoro- $\beta$-D-xylopyranoside (8) [14]}

Method A: The fluorination reaction of 7 (73 $\mathrm{mg}, 0.5 \mathrm{mmol})$ was carried out using TBABF (423 mg, $1.5 \mathrm{mmol}), \mathrm{KHF}_{2}$ (12 mg, $0.15 \mathrm{mmol}$ ), and heptane (1 ml) as solvent at $120{ }^{\circ} \mathrm{C}$ for $5 \mathrm{~h}$ as in the case of $\mathbf{1}$, and $\mathbf{8}(61 \mathrm{mg}, 0.37 \mathrm{mmol})$ was isolated by column chromatography (silica gel/AcOEt- $\mathrm{CH}_{2} \mathrm{Cl}_{2}$ ) in $70 \%$ yield. 
Method B: The fluorination reaction of 7 (101 mg, $0.5 \mathrm{mmol})$ was carried out using $\mathrm{Et}_{3} \mathrm{~N}-3 \mathrm{HF}$ (803 $\mathrm{mg}, 5 \mathrm{mmol}$ ) at $150{ }^{\circ} \mathrm{C}$ for $30 \mathrm{~min}$ as in the case of 1, and 8 (46 $\mathrm{mg}$, $0.28 \mathrm{mmol}$ ) was isolated by column chromatography (silica gel/AcOEt- $\mathrm{CH}_{2} \mathrm{Cl}_{2}$ ) in $55 \%$ yield. White solid: mp 102-104 ${ }^{\circ} \mathrm{C}$ (lit. [14] 104-105 ${ }^{\circ} \mathrm{C}$ ). $\quad$ IR (KBr) 3312, 2924, 1384 , 1065, $1028 \mathrm{~cm}^{-1} . \quad{ }^{1} \mathrm{H}$ NMR $\delta=2.35(\mathrm{~d}, J=3.7 \mathrm{~Hz}, 1 \mathrm{H}), 2.53(\mathrm{~d}, J=2.7 \mathrm{~Hz}, 1 \mathrm{H}), 3.30$ (dd, $J=9.8,11.7 \mathrm{~Hz}, 1 \mathrm{H}), 3.55(\mathrm{~s}, 3 \mathrm{H}), 3.57-3.65(\mathrm{~m}, 1 \mathrm{H}), 3.89-4.00(\mathrm{~m}, 1 \mathrm{H})$, 4.03-4.09 (m, 1H), 4.22 (d, $J=6.8 \mathrm{~Hz}, 1 \mathrm{H}), 4.39$ (ddd, $J=8.1,8.1,52.0 \mathrm{~Hz}, 1 \mathrm{H}) .{ }^{13} \mathrm{C}$ NMR $\delta=57.24,63.72\left(\mathrm{~d}, J_{\mathrm{C}-\mathrm{F}}=8.3 \mathrm{~Hz}\right), 68.39\left(\mathrm{~d}, J_{\mathrm{C}-\mathrm{F}}=19.0 \mathrm{~Hz}\right), 71.64\left(\mathrm{~d}, J_{\mathrm{C}-\mathrm{F}}=18.2\right.$ $\mathrm{Hz}), 95.42\left(\mathrm{~d}, J_{\mathrm{C}-\mathrm{F}}=181.9 \mathrm{~Hz}\right), 103.52\left(\mathrm{~d}, J_{\mathrm{C}-\mathrm{F}}=10.8 \mathrm{~Hz}\right) . \quad{ }^{19} \mathrm{~F}$ NMR $\delta=-205.36(\mathrm{ddt}$, $J=51.9,5.5,12.8 \mathrm{~Hz}, 1 \mathrm{~F})$.

3.4. Application for the fluorinated nucleoside derivative synthesis

3.4.1. 3-N-Methoxyethoxymethyl-2'-C- $\beta$-fluoromethyluridine (10) [15]

Method A: After complete removal of water from a mixture of the crude TBABF (423 mg, $1.5 \mathrm{mmol}$ ) and $\mathrm{KHF}_{2}$ (45 mg, $\left.0.15 \mathrm{mmol}\right), 9$ (55 mg, $\left.0.11 \mathrm{mmol}\right)$ and $\mathrm{CH}_{3} \mathrm{CN}$ (2 ml) were added, and the mixture was stirred at $60{ }^{\circ} \mathrm{C}$ for $24 \mathrm{~h}$. After cooling to room temperature, water $(2 \mathrm{ml})$ and ether $(2 \mathrm{ml})$ were added. The separated aqueous layer was extracted with ether three times, and the combined organic phase was dried over $\mathrm{MgSO}_{4}$ and concentrated under reduced pressure. Purification by column chromatography (silica gel/AcOEt- $\mathrm{CH}_{2} \mathrm{Cl}_{2}$ ) gave 10 (27 mg, $0.083 \mathrm{mmol}$ ) in 74\% yield. Viscous liquid: IR (neat) 3428, 2926, 1714, 1660, 1461, $1075 \mathrm{~cm}^{-1} \cdot{ }^{1} \mathrm{H}$ NMR $\left(\mathrm{CD}_{3} \mathrm{OD}\right) \delta=3.32(\mathrm{~s}, 3 \mathrm{H}), 3.30-3.35(\mathrm{~m}, 1 \mathrm{H}), 3.48-3.51(\mathrm{~m}, 2 \mathrm{H}), 3.72-3.74(\mathrm{~m}, 2 \mathrm{H})$, 
3.80-3.83 (m, 1H), 3.97-4.03 (m, 2H), 4.25-4.28 (m, 2H), 4.30 (dd, $J=10.0,45.6 \mathrm{~Hz}$, 1H), 4.47 (dd, $J=10.0,48.1 \mathrm{~Hz}, 1 \mathrm{H}), 5.41$ (s, 2H), 5.70 (d, $J=8.2 \mathrm{~Hz}, 1 \mathrm{H}), 6.04$ (s, 1H), $8.18(\mathrm{~d}, J=8.2 \mathrm{~Hz}, 1 \mathrm{H}) .{ }^{13} \mathrm{C} \mathrm{NMR} \delta=58.86,59.81,67.67,69.45,70.93,71.58$, $78.85\left(\mathrm{~d}, J_{\mathrm{C}-\mathrm{F}}=18.2 \mathrm{~Hz}\right), 81.57\left(\mathrm{~d}, J_{\mathrm{C}-\mathrm{F}}=175.3 \mathrm{~Hz}\right), 82.07,90.51,101.51,140.08$, 151.57, 163.06. ${ }^{19} \mathrm{~F}$ NMR $\left(\mathrm{CD}_{3} \mathrm{OD}\right) \delta=-225.90(\mathrm{t}, J=46.1 \mathrm{~Hz}, 1 \mathrm{~F})$.

\section{References and notes}

[1] J. T. Welch, S. Eswarakrishnan, Fluorine in Bioorganic Chemistry; Wiley: New York, 1991.

[2] K. Dax, M. Albert, J. Ortner, B. J. Paul, Carbohydr. Res. 327 (2000) 47-86.

[3] J. S. Fowler, T. Ido, Semin. Nucl. Med. 32 (2002) 6-12.

[4] M. W. Hager, D. C. Liotta, Tetrahedron Lett. 33 (1992) 7083-7086.

[5] A. A. Nikitenko, B. M. Arshava, I. E. Mikerin, Y. E. Raifeld, Tetrahedron Lett. 33 (1992) 7087-7088.

[6] G. Haufe, J. Fluorine Chem. 125 (2004) 875-894, and the references are cited therein.

[7] I. Lundt, D. Albanese, D. Landini, M. Penso, Tetrahedron 49 (1993) 7295-7300.

[8] J. Jünnemann, I. Lundt, J. Thiem, Acta Chemica Scandinavica 48 (1994) 265-268.

[9] Y. Akiyama, T. Fukuhara, S. Hara, Synlett (2003) 1530-1532.

[10] T. Inagaki, T. Fukuhara, S. Hara, Synthesis (2003) 1157-1159.

[11] J. Fuentes, M. Angulo, M. A. Pradera, Tetrahedron Lett. 39 (1998) 7149-7152.

[12] J. Fuentes, M. Angulo, M. A. Pradera, Carbohydr. Res. 319 (1999) 192-198.

[13] In the reaction of TBABF- $\mathrm{KHF}_{2}$ with a glycidol benzyl ether, which has an 
oxygen at $\alpha$-carbon of the epoxide, unusual high regioselectivity (98\%) was observed [9].

[14] M. Mastihubová, P. Biely, Carbohydr. Res. 339 (2004) 2101-2110.

[15] K. W. Pankiewicz, Carbohydr. Res. 327 (2000) 87-105.

[16] Q. Dai, J. A. Piccirilli, Org. Lett. 5 (2003) 807-810.

[17] I. Lundt, C. Pedersen, Synthesis (1992) 669-672.

[18] T. Soler, A. Bachki, L. R. Falvello, F. Foubelo, M. Yus, Tetrahedron: Asymmetry $11(2000)$ 493-517.

[19] L. Hough, J. K. N. Jones, J. Chem. Soc. (1952) 4349-4351.

[20] R. K. Sharma, J. L. Fry, J. Org. Chem. 48 (1983) 2112-2114.

[21] P. J. Card, G. S. Reddy, J. Org. Chem. 48 (1983) 4734-4743. 